\title{
Pengembangan Unit Kegiatan Belajar Mandiri (UKBM) Teks Anekdot Berbasis Higer Order Thinking and Skill (HOTS) untuk SMA
}

\author{
${ }^{1}$ Lailiyatus Sa'diyah, ${ }^{2}$ Sri Utami \\ ${ }^{1,2}$ Fakultas Ilmu Pendidikan dan Sosial, Universitas Nahdlatul Ulama Blitar \\ Jl. Masjid No. 22 Kota Blitar, Indonesia
}

Email: 1'Lailiyatus_Sadiyah@yahoo.com, ${ }^{2}$ utami3215@gmail.com

\begin{tabular}{l}
\hline Tersedia Online di \\
\hline http://www.jurnal.unublitar.ac.id/i \\
ndex.php/briliant \\
\hline Sejarah Artikel \\
\hline Diterima pada 10 September 2020 \\
Disetujui pada 8 Februari 2021 \\
Dipublikasikan pada 28 Februari \\
2021 \\
Hal. 1-10 \\
\hline
\end{tabular}

\begin{tabular}{l}
\hline Kata Kunci: \\
\hline Pengembangan; UKBM; Teks \\
Anekdot; HOTS \\
\hline
\end{tabular}

DOI:

http://dx.doi.org/10.28926/briliant. v3i4.547

\begin{abstract}
Abstrak: Penelitian ini merupakan inovasi pengembangan Unit Kegiatan Belajar Mandiri (UKBM) dengan teori Higer Order Thinking and Skill (HOTS) yang dirancang sebagai perangkat pendukung proses pembelajaran dalam penerapan sistem SKS di sekolah. Tujuan khusus penelitian ini berupa produk inovasi UKBM teks anekdot berbasis Higer Order Thinking and Skill (HOTS) untuk SMA dan juga mendiskripsikan kelayakan Unit Kegiatan Belajar Mandiri (UKBM) yaitu validitas, kepraktisan, kemenarikan, dan efektivitas produk Unit Kegiatan Belajar Mandiri (UKBM) Teks anekdot berbasis Higer Order Thinking and Skill (HOTS) untuk SMA. Metode penelitian yang digunakan adalah (R\&D) dengan lima tahapan dari sepuluh tahapan. Analisis data penelitian dilakukan secara kualitatif dan kuantitatif. Berdasarkan data tersebut hasil pengembangan produk Unit Kegiatan Belajar Mandiri (UKBM) teori Higer Order Thinking and Skill (HOTS) teks anekdot layak diimplementasikan untuk siswa SMA kelas X.
\end{abstract}

\section{PENDAHULUAN}

Pembaruan kurikulum dalam upaya peningkatan pendidikan telah dilakukan pemerintah dengan menerapkan kurikulum 2013. Unit Kegiatan Belajar Mandiri (UKBM) dan sistem kredit semester (SKS) menjadi salah satu implementasi dari kurikulum 2013 dan menjadi hal baru yang masih sangat jarang terjadi dipendidikan Indonesia. UKBM dalam kurikulum 2013 digunakan untuk mendukung pembelajaran dalam implementasi SKS dan ketuntasan belajar dan mulai uji coba tahun 2017/2018 di sekolah tertentu.

UKBM dirancang sebagai penunjang proses yang utuh dengan Sistem Kredit Semester (SKS). UKBM memiliki karakteristik lebih mengutamakan kemandirian siswa dan diharapkan mampu menyelesaikan pendidikannya lebih cepat dari periode belajar secara umum (Direktorat Pembinaan SMA, 2017). Implementasi Sistem Kredit Semester (SKS) dituntut mampu menyediakan UKBM yang merupakan satuan pelajaran yang kecil yang disusun secara berurutan dari yang mudah sampai ke yang sukar (Kemendikbud, 2017:3). UKBM menjadi sebuah media atau bahan belajar dalam pembelajaran bahasa Indonesia. 
Diterapkannya UKBM menjadi daya pikat dikarenakan proses pelaksanaanya berkaitan langsung dengan peserta didik dan menuntut kemandirian peserta didik. Dengan adanya Unit Kegiatan Belajar Mandiri akan merubah sistem dan proses pembelajaran pada umumnya di kelas. Namun, terjadi beberapa permasalahan di sekolah dalam penerapannya. Berdasar pada hasil observasi dan wawancara yang dilakukan, peserta didik kelas $\mathrm{X}$ dalam menyelesaikan Unit Kegiatan Belajar Mandiri (UKBM) khususnya teks anekdot masih menguji aspek ingatan dan belum melatih keterampilan berpikir tingkat tinggi peserta didik. Unit Kegiatan Belajar Mandiri (UKBM) belum sepenuhnya disusun berdasarkan prinsip-prinsip penyusunan yaitu dari mudah ke sukar. Di samping itu, guru masih memiliki kendala dalam mengembangkan Unit Kegiatan Belajar Mandiri (1) guru masih melakukan ceramah, (2) Unit Kegiatan Belajar Mandiri teks anekdot peserta didik masih belum tersusun sesuai dengan tujuan pembalajaran, (3) Unit Kegiatan Belajar Mandiri teks anekdot peserta didik masih belum tersusun sesuai hasil analisis KI-KD, (4) Soal-soal formatif yang belum mencerminkan kemampuan berpikir tingkat tinggi. Sehingga pembelajaran yang seharusnya mampu mencukupi kebutuhan revolusi 4.0 yang melibatkan kemampuan berpikir tingkat tinggi dan pemenuhan SDM yang berdaya saing belum terwujud.

Penelitian terkait UKBM masih sangat minim. Sebuah penelitian yang dilakukakan Fajriyah (2018) tentang pengembangan UKBM Hukum Newton Berbasis Core (Content Representasion) untuk meningkatkan Pemahaman Konsep. Didapatakan hasil yang menunjukkan peningkatan pemahaman dan respon positif terhadap UKBM yang dinilai sangat layak digunakan dalam pembelajaran. Penelitian Arini tentang Pengaruh Penggunaan BTP (Buku Teks Pelajaran) dalam UKBM terhadap hasil Belajar kelas IX IPS 2 SMA Negeri 7 Malang, menyimpulkan bahwa buku teks pelajaran sangatlah berpengaruh terhadap hasil belajar dan kemandirian siswa dalam menyelesaikan UKBM.

Hal inilah yang menjadi dasar perlunya dikembangkan Unit Kegiatan Belajar Mandiri teks anekdot yang berbasis Higer Order Thinking and Skill (HOTS). Dengan pengembangan keterampilan berpikir aras tinggi peserta didik diaharapkan mampu dan mahir dalam memecahkan masalah teks anekdot manjadi baik, keyakinan menyelesaikan UKBM meningkat, dan meningkatmya kemampuan berpikir aras tinggi.

\section{METODE}

Pada penelitian ini menerapkan Research and Development (R\&D) dari Borg dan Gall, yaitu penelitian yang digunakan untuk menghasilkan produk tertentu dan menguji keefektifan produk tertentu (Sugiyono, 2014: 407) digunakan dalam penelitian pengembangan ini. Penerapannya Lima tahap dari sepuluh tahap yang dikemukakan Borg dan Gall dengan alur pengembangan sebagai berikut. (1) penelitian dan pengumpulan data (research \& information collector) untuk studi pendahuluan berupa langkah observasi dan wawancara untuk menghasilkan temuan sementara penyesunan Unit Kegiatan Belajar Mandiri (UKBM). (2) Perencanaan (planning) berupa rancangan produk dan proses pengembangannya. (3) pengembangan draf produk awal (develope premliminary form of product) dengan penyusunan KI, KD, tujuan, materi ajar, rpp, pengembangan produk awal. (4) uji coba lapangan awal (preminary field testing) dengan uji kepraktisan pada guru 
bahasa Indonesia, dan uji kemenarikan serta keefektifan pada peserta didik kelompok kecil. (5) revisi produk utama (main product revision) yaitu revisi besar terhadap hasil uji coba produk utama dilakukan dengan cara menganalisis semua catatan, komentar, masukan, dan saran-saran dari uji validasi oleh para ahli, uji kepraktisan oleh guru, dan uji kemenarikan serta keefektifan oleh peserta didik.

Penelitian ini melibatkan Madrasah Aliyah Negeri di Tulungagung dengan tiga kelompok subjek uji coba validasi produk (1) ahli pengembang dan pembelajarannya, (2) dua orang guru bahasa Indonesia, (3) peserta didik kelas X. Sesuai dengan konteks implementasi K13 memberikan kewenangan guru mengembangkan UKBM dan melibatkan guru dalam tim partisipatif dalam penyusunan dan memberi pengalaman guru dalam menyusun UKBM.

Pengumpulan data dalam penelitian ini menggunakan instrumen berupa angket, pedoman wawancara, dan lembar tes. Angket untuk uji ahli (ahli pengembang dan pengajarannya. Guru bahasa Indonesia, dan kelompok kecil peserta didik. Pedoman wawancara digunakan mengklarifikasi komentar tertulis yang belum jelas untuk peneliti. Lembar tes untuk mengetahui keefektifan penggunaan UKBM dari tes uji kompetensi peserta didik.

Penelitian ini dalam analisis data menggunakan teknik kualitatif dan kuantitif. Data kualitatif diperoleh dari hasil wawancara dan catatan tertulis yaitu komentar pada angket. Teknik kuantitaf yaitu angket penilaian produk UKBM. Data dari angket tentang kelayakan UKBM erupa tingkat validitas, kepraktisan, kemenarikan, dan efektivitas produk UKBM dianalisis dengan teknik kuantitaif sederhana dengan meghitung presentase jawaban tiap item pertanyaan. Pengolahan data angket yang telah divalidasi dianalisis dengan rumus $P=\mathrm{x} / \mathrm{xix} 100 \%$ dan pengolah data keseluruhan item $P=x / x i \times 100 \%$. Penafsiran hasil analisis data menggunakan interpretasi berdasarkan Sugiyono (2014:417-421), yaitu (1) jika aspek Unit Kegiatan Belajar Mandiri diuji kelayakanya mencapai presentase 86\%$100 \%$, maka Unit Kegiatan Belajar Mandiri dapat dikulifikasikan sangat layak dan diimplementasikan, (2) jika aspek Unit Kegiatan Belajar Mandiri diuji kelayakanya mencapai presentase 76\%-85\%, maka Unit Kegiatan Belajar Mandiri dapat diklasifikasikan layak diimplementasikan, (3) jika aspek Unit Kegiatan Belajar Mandiri diuji kelayakanya mencapai presentase 56\%-75\% maka Unit Kegiatan Belajar Mandiri dapat dikatakancukup layak dan direvisi, (4) apabila aspek Unit Kegiatan Belajar Mandiri diuji kelayakanya mencapai presentase $<55 \%$ maka Unit Kegiatan Belajar Mandiri dapat dikulifikasikan kurang layak dan revisi.

\section{HASIL}

\section{Penyajian Data Uji Ahli dan Uji Coba Lapangan}

HOTS merupakan tingkat kemampuan berpikir di atas tingkatan menghafal. Penyampaian informasi kembali, menghubungkan, memanipulasi, dan mentransformasi pengalaman secara kritis dan kreatif sehingga dapat memecahkan maslah dalam mengambil keputusan dalam situasi baru (Sunarno, 2018). Level HOTS tersusun menjadi 6 tingkatan, yaitu knowledge, comprehenson, application, analysis, synthesis, dan evaluation. Sejalan dengan itu Ramli (2015) menyederhanakan konsep HOTS menjadi knowledge dan intellectual skills. Unit Kegiatan Belajar Mandiri (UKBM) berbasis Higer Order Thinking and Skil 
(HOTS) untuk SMA kelas X dikembangkan mecakup sistematika penyajian, isi, tampilan. Dengan uji kelayakan produk dilakukan melalui tiga langkah; (1) ahli pengembang Unit Kegiatan Belajar Mandiri (UKBM) bidang pendidikan bahasa Indonesia pembelajaranya. (2) dua orang guru bahasa Indonesia (3) uji kemenarikan dan keefektifan diujikan pada siswa kels X.

Penelitian ini memiliki data kuantatif dan kualitatif. Data kuantitatif didapatkan dari hasil angket validasi uji ahli pengembangan UKBM dan pembelajarannya, uji coba guru dan uji coba siswa kelas $\mathrm{X}$ dengan komponen penilaian isi, sistematika dan tampilan UKBM.

Selanjutnya hasil penilaian isi ahli pengembang bidang pendidikan bahasa Indonesia dan pembelajarannya memeroleh persentase $86,5 \%$ sehingga isi pada produk unit kegiatan belajar mandiri (UKBM) sangat layak diimplementasikan dalam pembelajaran. Hasil uji coba lapangan penilaian isi UKBM dilakukan terhadap guru bahasa Indonesia memeroleh persentase 91,7\% sehingga isi produk UKBM dinyatakan sangt layak untuk digunakan dalam pembelajaran bahasa Indonesia. Selanjutnya, hasil data uji coba lapangan pada pesrta didik memeroleh persentase $100 \%$ sehingga komponen isi produk UKBM berbasis HOTS sangat layak diimplemantasikan dalam pembelajaran teks anekdot di SMA.

Berdasarkan hasi penilaian sistematika berupa kepraktisan atau kemenarikan oleh ahli pengembang UKBM bidang pendidikan bahasa Indonesia dan pembelajarannya memeroleh persentase $100 \%$ artinya produk UKBM sangt layak digunakan untuk pembelajaran. Data hasl uji coba lapangan untuk nilai kepraktisan atau kemenarikan UKBM terhadap guru bahasa Indonesia memeroleh persentase 94,7\% sehingga kepraktisan dan kemenarikan produk UKBM dinyatakan sngat layak untuk pembelajaran bahasa Indonesia. Selanjutnya, hasil data uji coba lapangan pada peserta didik penilaian sistematika berupa kepraktisan atau kemenarikan memeroleh persentase $100 \%$ sehingga produk UKBM berbasis HOTS sangat layak diimplemantasikan untuk pembelajaran teks anekdot di SMA.

Berdasarkan hasi penilaian efektivitas oleh ahli pengembang bidang pendidikan bahasa Indonesia dan pembelajarannya memeroleh persentase $100 \%$ artinya produk UKBM sangat layak digunakan dalam pembelajaran. Hasil data uji coba lapangan penilaian efektivitas terhadap guru bahasa Indonesia memeroleh persentase $93,78 \%$ sehingga efektivitas produk UKBM dinyatakan sngat layak untuk pembelajaran bahasa Indonesia. Selanjutnya, hasil data uji coba lapangan pada siswa penilaian sistematika berupa efektivitas memeroleh persentase $98 \%$ sehingga produk UKBM berbasis HOTS sangat lyak diimplemantasikan dalam pembelajaran teks anekdot jenjang SMA.

Hasil pengembangan produk dalam penelitian ini berupa Unit Kegiatan Belajar Mandiri (UKBM) teks anekdot kelas X SMA. Kompetensi dasar yang menjadi dasar penyusunan UKBM ini sebagai berikut. (1) Kompetensi Dasar 3.5 mengevaluasi teks anekdot dari aspek makna tersirat dengan Indikator Pencapaian Kompetensi (IPK) meliputi: (a) menentukan teks anekdot dari aspek makna tersirat, (b) mengurutkan teks anekdot dari aspek makna tersirat dan (c) mengaitkan teks anekdot dari aspek makna tersirat (d) memecahkan teks anekdot dari aspek makna tersirat (e) menyusun makna tersirat dalam sebuah teks anekdot. (2) KD 3.6 Menganalisis struktur dan kebahasaan teks Anekdot, dengan Indikator Pencapaian Kompetensi (IPK) meliputi: (a Menemukan struktur dan kebahasaan teks anekdot. 
(b) Menyimpulkan struktur dan kebahasaan teks anekdot.(c) Merinci struktur dan kebahasaan teks anekdot.(d) Menganalisis struktur dan kebahasaan teks anekdot (e) Mempraktikkan kembali teks anekdot dengan memerhatikan struktur dan kebahasan, baik lisan maupun tulis.

\section{Penyajian Data Uji Coba Lapangan}

Uji kelayakan Unit Kegiatan Belajar Mandiri (UKBM) dilakukan melalui tiga tahap uji pertama, uji ahli pengembang dan pembelajara kedua, uji guru bahasa Indonesia ketiga, uji coba siswa. Uji ahli terhadap produk UKBM dilakukan terhadap dua orang guru, dan kelas X-MIPA 3

Terdapat kriteria pemberian skor pada angket. Kriteria 1 menunjukkan UKBM krang layak sehingga harus direvisi, kriteria 2 menunjukkan UKBM cukup layak namun harus direvisi, kriteria 3 menunjukkan UKBM layak sehingga layak diimplementasikan, dan kriteria 4 UKBM sangat layak diimplementasikan. selanjutnya dilakukan terhadap empat kriteria produk yang telah diuji, data numerik hasil uji dipersntasikan sesuai dengan pedoman interprtasi kevalidan UKBM supaya diketahui tingkat kevalidannya. Empat kriteria penyekoran uji coba kevalidan tersebut dirinci sebagai berikut.

1) Jika kelayakan UKBM $86 \%$ - 100\%, maka UKBM dikualifkasikan sangat layak diimplementasikan dan dapat dipakai untuk pembelajaran teks anekdot untuk SMA kelas X.

2) Jika kelayakan UKBM 76\% - 85\%, maka UKBM dikualifkasikan layak diimplementasikan dan dapat dipakai untuk pembelajaran teks anekdot untuk SMA kelas X.

3) Jika kelayakan UKBM 56\% - 75\%, maka UKBM dikualifkasikan cukup layak dan revisi sehingga belum dapat dipakai untuk pembelajaran teks anekdot untuk SMA kelas X.

4) Jika kelayakan UKBM $<55 \%$, maka UKBM dikulifikasikan kurang layak dan harus revisi dalam pembelajaran teks anekdot untuk SMA kelas X.

Tabel 1. Hasil Validasi isi Ahli Pengembang dan Pembelajaran

\begin{tabular}{|c|c|}
\hline \multicolumn{2}{|c|}{ DATA NUMERIK } \\
\hline Indikator Penilaian & Penilaian \\
\hline $\begin{array}{l}\text { 1. Penilaian kelayakan isi } \\
\text { a. Kedalaman materi UKBM } \\
\text { b. Kelengkapan materi pada UKBM } \\
\text { c. Keakuratan latihan UKBM } \\
\text { d. Pendukung materi pada UKBM }\end{array}$ & $\begin{array}{l}3 \\
3 \\
4 \\
4\end{array}$ \\
\hline Rata-rata & $87.5 \%$ \\
\hline $\begin{array}{l}\text { 2. Penyajian langkah-langkah } \\
\text { a. Sistem penyajian dalam UKBM } \\
\text { b. Penyajian pembelajaran dalam UKBM } \\
\text { c. Kelengkapan penyaian UKBM }\end{array}$ & $\begin{array}{l}4 \\
3 \\
4\end{array}$ \\
\hline Rata-rata & $91.7 \%$ \\
\hline
\end{tabular}

BRILIANT: Jurnal Riset dan Konseptual Volume 6 Nomor 1, Februari 2021 


\begin{tabular}{|l|c|}
\hline $\begin{array}{l}\text { 3. Kesesuaian landasan UKBM } \\
\text { a. Ketetapan landasan untuk UKBM } \\
\text { b. Ketetapan langkah-langkah dalam UKBM }\end{array}$ & 3 \\
\hline \multicolumn{1}{|c|}{ Rata-rata } & 3 \\
\hline 4. Relevensi tampilan UKBM & $\mathbf{7 5 \%}$ \\
a. Ukuran UKBM Rata-rata & 3 \\
b. Desain tampilan dalam UKBM & 4 \\
c. Desain isi dalam UKBM & 4 \\
\hline & $\mathbf{9 1 . 7 \%}$ \\
\hline Jumlah keseluruhan & $\mathbf{4 2}$ \\
\hline Rata-rata keseluruhan & $\mathbf{8 7 . 5 \%}$ \\
\hline Kriteria keseluruhan & Sangat Layak \\
\hline
\end{tabular}

Hasil validasi ahli pengembang dan pembelajaran berdasarkan tabel diatas bahwa produk UKBM telah dikembngkan masuk dalam kualifikasi sangat layak, namun masih ada beberapa kesalahan produk yang harus direvisi. Secara numerik, kelayakan isi UKBM mendapat persentase 87,5\%. Penyajian langkah-langkah UKBM mendapat persentase $91,7 \%$. Kesesuaian landasan UKBM mendapat skor 75\% dan Relevensi tampilan dalam UKBM dengan presentase 91,7\%. Dari keempat kriteria tersebut, rata-rata persentase dari ahli pembelajaran diperoleh $87,5 \%$. Skor tersebut masuk dalam kualifikasi sangat layak karena berada pada rentangan $86 \%-100 \%$. Hal tersebut berarti produk dapat diimpelemntasikan dalam pembelajaran.

Tabel 2. Hasil Validasi Ahli Media Pembelajaran

\begin{tabular}{|l|c|}
\hline \multicolumn{1}{|c|}{ DATA NUMERIK } & \\
\hline \multicolumn{1}{|c|}{ Indikator Penilaian } & Penilaian \\
\hline 1. Kesesuaian isi dengan tampilan media & 3 \\
a. Kemudahan memahami penggunaan UKBM & 4 \\
b. Ketepatan UKBM menjadi bahan ajar pendukung & 3 \\
c. UKBM sebagai pendukung siswa belajar secara mandiri & 4 \\
d. Ketepatan UKBM dalam mendorong kreatifitas siswa & 3 \\
e. Ketepatan UKBM dalam mendorong siswa untuk berfikir kritis & \\
dan interaktif & $\mathbf{8 5 \%}$ \\
\hline \multicolumn{1}{|c|}{ Rata-rata } & \\
\hline 2. Kesesuaian tampilan media & 4 \\
a. Ketetapan desain sampul pada UKBM & 3 \\
b. Ketetapan desain background pada UKBM & 3 \\
c. Ketetapan jenis huruf pada UKBM & 3 \\
d. Ketetapan warna desain pada UKBM & 3 \\
e. Kesesuaian gambar yang terdapat pada UKBM & $\mathbf{8 0 \%}$ \\
\hline Rata-rata & $\mathbf{3 3}$ \\
\hline Jumlah keseluruhan & $\mathbf{8 2 , 5 \%}$ \\
\hline Rata-rata keseluruhan & Layak \\
\hline Kriteria keseluruhan &
\end{tabular}

Tabel di atas menunjukkan bahwa hasil validasi dari ahli media pembelajaran terdiri dari data numerik dan data verba. Secara numerik, data validasi ahli media menunjukkan penilaian kesesuaian media memiliki rata-rata $85 \%$ masuk 
kriteria Layak. Pada penilaian kesesuaian tampilan, rata-rata skor $80 \%$ dengan kriteria Layak. Secara keseluruhan, rata-rata yang diperoleh dari penelian aspek kelayakan isi, dan penyajian yaitu $82,5 \%$ Skor tersebut masuk dalam kualifikasi Layak karena berada pada rentangan $76 \%-85 \%$. Hal tersebut berarti produk dapat diimpelemntasikan dalam buku siswa.

\section{PEMBAHASAN}

Hasil analisis data menunjukkan produk UKBM teks anekdot untuk SMA memenuhi kriteria kelayakan.

\section{Pengkajian Produk}

Hasil produk UKBM teks anekdot berbasis HOTS untuk SMA pada komponen pertama validasi isi UKBM memenuhi keterpaduan KI dan KD, tujuan pembelajaran sesuai untuk pencapaian $\mathrm{KD}$, mengevaluasi ketercapaian $\mathrm{KD}$, adanya tes dan soal-soal formatif sudah mencerminkan kemampuan berpikir tingkat tinggi, dan kelengkapan bahan. Sejalan dengan pendapat Muslich (2013:3) terdapat tiga indkator dalam kelayakan isi, kepaduan materi dengan KD dan kebenaran bahan.

Komponen kedua kepraktisan atau kemenarikan memenuhi komposisi yang menarik sesuai dengan minat peserta didik sejalan dengan pendapat (Muslich, 2015:53). Kepraktisan dan kemenarikan UKBM memenuhi sifat komunikatif, hangat, cerdas dan ramah. Komponen ketiga efektivitas memenuhi prinsip SKS untuk pembelajaran mandiri setiap peserta didik secara efektif dan efisien. Serta mningkatkan intelegensi, minat dan bakat sesuai dengan perkembangan dan kemampuan peserta didik. Sehingga peserta didik mudah untuk belajar memahami materi, soal-soal dari setiap KD dan meningkatakan keterampilan berpikir tingkat tinggi yang lebih spesifik seperti penalaran, kemampuan analisis, pemecahan masalah (Zuhri, 2018:5).

\section{Revisi Produk}

Uji coba dengan ahli pengembang dan pembelajaran, guru bahasa Indonesia, dan siswa kelas $\mathrm{X}$ menunjukkan hasil yaitu, perlu dilakukan beberapa revisi terhadap produk UKBM yaitu (1) isi, (2) penyajian, (3) tampilan. Komponen isi didapat skor rata-rata $87,5 \%$, sehingga isi pada produk UKBM teks anekdot berbasis HOTS untuk siswa SMA dapat dikatakan layak diimplementasikan untuk pembelajaran. Saran yang diberikan yaitu jumlah teks anekdot perlu ditambahkan. Teks dapat lebih dari satu. Hal ini untuk memberikan khasanah teks anekdot. Hasil kompnen isi oleh ahli pembelajaran diperoleh persentase 91,7\%, dinyatakan sangt layak untuk pembelajaran. Saran yang diberikan yaitu aspek pengetahuan kegiatan belajar 1 tugas 1 perlu diubah pada bagian keterampilan membaca. Seharusnya, kegiatan membaca bukan oleh guru yang didengar siswa, melainkan siswa membaca secara individual teks anekdoy Hal ini untuk mengefektifkan kegiatan pembelajaran. Berikut komponen isi produk sebelum direvisi. 


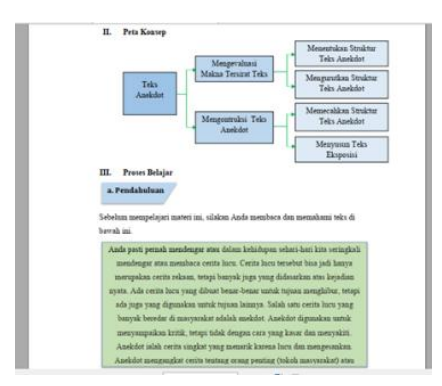

Gambar 1. UKBM belum direvisi

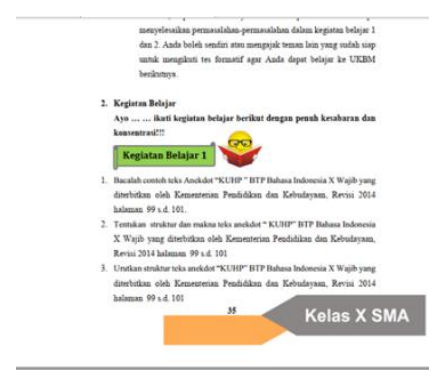

Gambar 2. UKBM sudah direvisi

Hasil komponen isi dari guru bahasa Indonesia diperoleh presentase rata-rata 100 $\%$, sehingga isi produk UKBM teks anekdot berbasis HOTS untuk SMA dinyatakan sangat layak untuk pembelajaran di SMA.

\section{Revisi Sistematika Penyajian}

Berdasarkan uji ahli pembelajaran, komponen sistematika didapatkan hasil $100 \%$, sehingga produk UKBM dinyatakan sangat layak untuk diimplementasikan untuk pembelajaran. Selanjutnya dilakukan uji coba lapangan pada guru bahasa Indonesia diperoleh presntase $93,75 \%$,dan dinyatakan sangat layak untuk pembelajaran. Saran yang diberikan oleh guru bahasa Indonesia yaitu Sistematika penyajian pembelajaran diurutkan kembali sesuai tujuan pembelajaran. Berikut tampilan produk UKBM sebelum dan sesudah direvisi.

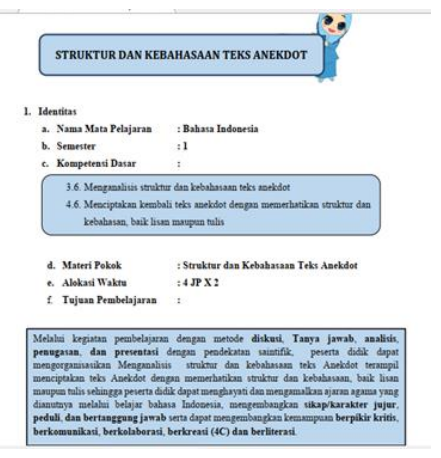

Gambar 3. UKBM Belum Direvisi

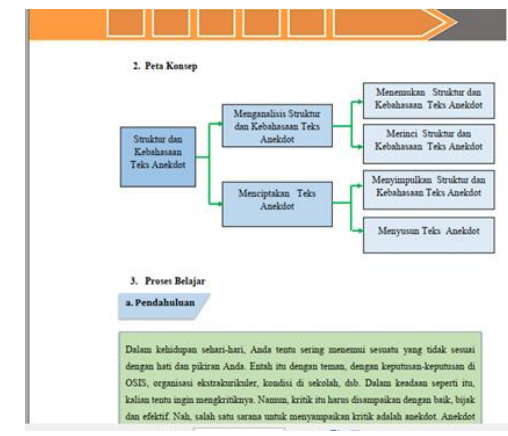

Gambar 4. UKBM sudah direvisi

Hasil revisi sistematika penyajian diperoleh prsentase 95\% terhadap siswa kelas X di MAN 3 Tulungagung. Prsentase tersebut menunjukkan bahwa produk UKBM teks anekdot berbasis HOTS sangat layak diimplemntasikan untuk pemblajaran di sekolah.

\section{Revisi Tampilan}

Berdasarkan hasil penilaian tampilan ahli pengembang, ahli pembelajaran, guru, dan peserta didik. Komponen tampilan dengan presentase rata-rata 77,78\%, sehingga dinyatakan produk UKBM layak dimplementasikan dalam pembelajaran. Penilaian tampilan ahli pembelajaran diperoleh skor dengan presentase 83,3\%, shingga pada komponen tampilan produk UKBM dinyatakan layak diterapkan. Saran yang diberikan yaitu (1) desain sampul perlu ditata yang lebih sederhana. (2) 
Warna huruf dalam isi UKBM jangan terlalu menggunakan lebih dari dua warna. Sebaiknya, warna pada huruf menggunakan satu-dua warna. Hal ini dapat membantu konsentrasi siswa dalam belajar. (3) Perlu mencantumkan sumber gambar dan teks. Berikut ini hasil revisi sebelum dan sesudah.

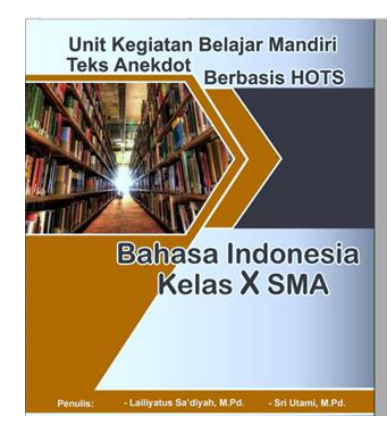

Gambar 5. sampul UKBM belum direvisi

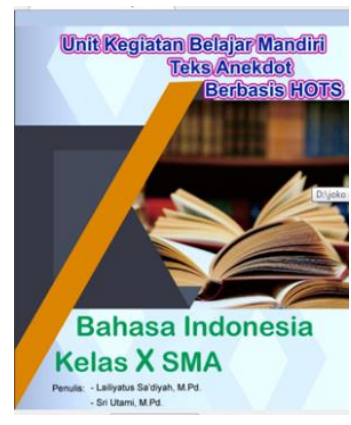

Gambar 6. Gambar sampul UKBM setelah direvisi

Setelah revisi tampilan, data uji coba lapangan oleh guru bahasa Indonesia SMA menunjukkan poresentase 85,94\%, menyatakan komponen tampilan layak diterapkan dalam pembelajaran di SMA.

\section{KESIMPULAN}

Berdasarkan pembahasan produk (UKBM) teks anekdot berbasis Higer Order Thinking and Skill (HOTS) untuk kelas X SMA dapat disimpulkan bahwa menurut para ahli pembelajaran, ahli media atau guru, serta penilaian siswa persentase kelayakan UKBM teks anekdot Higer Order Thinking and Skill (HOTS) untuk kelas X SMA mencapai kriteria sangat layak. Hal ini menunjukkan bahwa UKBM dapat digunakan dengan revisi sehingga menghasilkan produk yang lebih baik. Dengan demikian Unit Kegiatan Belajar Mandiri (UKBM) teks anekdot berbasis Higer Order Thinking and Skill (HOTS) untuk kelas X SMA ini dapat digunakan menjadi alternatif evaluasi pembelajaran di SMA.

\section{SARAN}

Saran pemanfaatan produk Unit Kegiatan Belajar Mandiri (UKBM) teks anekdot berbasis Higer Order Thinking and Skill untuk kelas X SMA ini agar dapat digunakan sebagai pelengkap BTP yang telah digunakan di sekolah. Selain itu, UKBM ini dapat digumnakan menganalisis isi dan mengontruksi teks anekdot. Selian itu UKBM ini dapat digunakan oleh guru bahasa Indonesia sebagai rujukan latihan-latihan soal yang lebih variatif. Sedangkan bagi peneliti lain, dapat dikembangkan dan digunakan sebagai inspirasi menemukan ide untuk mengembangkan produk lain yang sejalan dengan UKBM ini. Selain itu, produk ini juga dapat dijadikan sebagai rujukan dalam penyusunan UKBM teks-teks lain.

\section{DAFTAR RUJUKAN}

Brookhart S.M. 2010. How to Asses Higher Order Thinking Skills in Your Clasroom. Alexandria: ASCD 
Direktorat Pembinaan SMA. 2017. Panduan Pengembangan Unit Kegiatan Belajar Mandiri (UKBM). Jakarta : Kementerian Pendidikan dan Kebudayaan.

Fajriyah, M.I. 2018. Pengembangan Unit Kegiatan Belajar Mandiri (UKBM) Hukum Newton Berbasis CoRe (Content Representation) untuk Meningkatkan Pemahaman Konsep. Skripsi Pendidikan Fisika Universitas Negeri Malang.

Kemendikbud. 2017. Bahasa Indonesia: Buku Guru edisi Revisi. Jakarta: Kementerian Pendidikan dan Kebudayaan RI.

Lewis, A and Smith, D. 1993. Defining High Order Thinking Theory IntoPractice Collage of Education. Ohio: The Ohio State University.

Muslich, M. 2013. Text Book Writing. Dasar-Dasar Pemahaman Pemakaian Buku Teks. Jojakarta: Ar-Ruzz Media.

Ramli, Murni.2015. "Pengembangan Model dan Perangkat Pembelajaran untuk Meningkatkan Kemampuan Berpikir Tingkat Tinggi” Prosiding Seminar Nasional Pendidikan Sains (SNSP) V. Surakarta : UNS.

Sugiyono. 2014. Metode Penelitian Kuantitatif Kualitatif dan R\&D. Bandung: ALFABETA

Purwanto, M.NG. 2013. Prinsip-Prinsip dan Teknik Evaluasi Pengajaran (Cetakan kedelapan belas). Bandung: PT. Remaja Rosda Karya.

Suherli. 2016. Buku Guru Bahasa Indonesia. Pusat Kurikulum dan Perbukuan, Balitbang, Kemdikbud.

Zuhri, M.dkk. 2018. Buku Pegangan Pembelajaran Berorientasi pada Keterampilan Berpikir Tingkat Tinggi: Program Peningkatan Kompetensi Pembelajaran Berbasis Zonasi. Jakarta: Dirjen Guru dan Tenaga Kependidikan Kemendikbud. 